http://dx.doi.org/10.1590/1678-4162-8594

Arq. Bras. Med. Vet. Zootec., v.69, n.1, p.139-145, 2017

\title{
Genotyping of Toxoplasma gondii isolates from naturally infected Gallus domesticus in Santa Catarina state, Brazil
}

\author{
[Genotipagem de Toxoplasma gondii isolados de Gallus domesticus naturalmente infectados \\ no estado de Santa Catarina, Brasil] \\ N. Trevisani ${ }^{1}$, L.D. Barros ${ }^{2}$, A. Vieira-Neto ${ }^{1}$, A.A. Sartor ${ }^{1}$, A.P. Souza ${ }^{1}$, \\ J.L. Garcia ${ }^{2}$, A.B. Moura ${ }^{1 *}$ \\ ${ }^{1}$ Universidade do Estado de Santa Catarina - Udesc - Lages, SC \\ ${ }^{2}$ Universidade Estadual de Londrina - UEL - Londrina, PR
}

\begin{abstract}
Toxoplasmosis is a widespread zoonosis that can infect warm-blooded animals including birds and humans, and chickens are considered to be indicators of environmental contamination. In Brazil, Toxoplasma gondii has a non-clonal population structure composed of three lineages (I, II, and III), presenting high recombination, and resulting in wide genetic diversity. This study aimed to genetically characterize T. gondii isolates from naturally infected chickens (Gallus domesticus) in Santa Catarina state, southern Brazil region. Sera from 133 free-range chickens were analyzed by an immunofluorescence assay (IFA) to detect IgG antibodies against $T$. gondii. Brain and heart from 30 positive animals, based on IFA ( $\geq 1: 64)$, were used to isolate the parasite using a mouse bioassay. Strain genotyping was performed by PCR-RFLP using 12 genetic markers (SAG1, 5'-3'SAG2, alt. SAG2, SAG3, BTUB, GRA6, c22-8, c29-2, L358, PK1, Apico, and CS3). The results were classified according to the genotypes based on the ToxoDB (http://toxodb.org/toxo/). Of 133 chicken sera analyzed, 84 $(63.16 \%)$ were positive, with antibody titers ranging from 16 to 1024 . Eleven isolates were obtained from mouse bioassay (Ck3, Ck32, Ck35, Ck56, Ck63, Ck89, Ck102, Ck103, Ck125, Ck127, and Ck128). Genotyping revealed six genotypes; three were classified as \#26, \#53, and \#120, and three (NEO1, NEO2, and NEO3) were had not been previously described. No clonal lineages of type I, II, or III were identified. The present study confirms the high genetic diversity of $T$. gondii in Brazil.
\end{abstract}

Keywords: Toxoplasma gondii, Gallus domesticus, genotyping, Brazil

\section{RESUMO}

A toxoplasmose é uma zoonose de ampla distribuição, que acomete animais homeotérmicos, incluindo as aves e o ser humano. Galinhas podem ser consideradas indicadoras de contaminação ambiental. No Brasil, Toxoplasma gondii não apresenta estrutura populacional clonal (I, II e III), ocorrendo alta frequência de recombinação, o que resulta na grande diversidade genética observada. O presente trabalho teve como objetivo caracterizar geneticamente T. gondii de galinhas (Gallus domesticus) naturalmente infectadas do estado de Santa Catarina. Soros de 133 aves criadas extensivamente foram analisados pela reação de imunofluorescência indireta (RIFI) para detecção de anticorpos IgG contra $\mathrm{T}$. gondii. Para o isolamento do parasito (bioensaio em camundongos), foram utilizados coração e cérebro de 30 aves que apresentaram títulos maiores que 64 na RIFI. Os isolados obtidos foram submetidos à caracterização genotípica por meio da RFLP-PCR utilizando 12 marcadores genéticos (SAG1, 5'3'SAG2, alt.SAG2, SAG3, BTUB, GRA6, c22-8, c29-2, L358, PK1, Apico e CS3). Os resultados obtidos foram classificados de acordo com os genótipos presentes no ToxoDB (http://toxodb.org/toxo/). Das 133 amostras de soros de galinha analisadas, 84 (63,16\%) foram positivas, com títulos de anticorpos variando de 16 a 1024. No bioensaio, foram obtidos 11 isolados (Ck 3, Ck 32, Ck 35, Ck 56, Ck 63, Ck

Recebido em 16 de julho de 2015

Aceito em 9 de agosto de 2016

*Autor para correspondência (corresponding author)

E-mail: anderson.moura@udesc.br 
89, Ck 102, Ck 103, Ck 125, Ck127 e Ck 128). A análise genotípica revelou a presença de seis genótipos, três dos quais classificados como \#26, \#53 e \#120, e três, NEO1, NEO2 e NEO3, não descritos anteriormente. Nenhuma linhagem clonal I, II ou III foi encontrada. O presente trabalho confirma a ampla diversidade genética do parasito observada no Brasil.

Palavras-chave: Toxoplasma gondii, Gallus domesticus, genotipagem, Brasil

\section{INTRODUCTION}

Currently there is great interest in the biology of different $T$. gondii genotypes, as well as in the virulence of many strains. Several markers have been evaluated to study the population structure of this parasite and to assess possible associations with virulence. Isozyme analysis and RFLP markers were initially used. $T$. gondii genome sequencing provided access to a large number of genetic markers, and current studies require the use of multiple markers for "multilocus" analysis (Dardé et al., 2007).

According to Howe and Sibley (1995), T. gondii has a highly clonal population structure consisting of three predominant lineages designated as I, II and III, indicating that its propagation in nature occurs mainly through asexual propagation or uniparental reproduction. This feature is evident by the isolation of strains with identical genotypes from different hosts in different geographical areas. In a strongly clonal population structure, biological characteristics such as virulence can be attributed to genetically defined subgroups of the population (Dardé $e t$ al., 2007). Despite the fact that studies in vivo and in vitro have shown that each parasite genotype has its own characteristics, virulence typically depends on a balance between parasite and host features, and thus a very large range of variation occurs (Dardé et al., 2007).

The analysis of isolates collected in South America, Africa, and Asia showed a predominance of non-archetypal strains in these regions, which are usually more virulent in mice than type II strains, which are more common to Europe and North America (Maubon et al., 2008).

Free-range chickens can develop T. gondii tissue cysts, which represent a potential risk for human infection (Literak and Hejlicek, 1993). Dubey et al. (1993) observed seroconversion after experimental inoculations in chickens and found cysts in the brain, heart, and muscle tissues.
Studies by Kaneto et al. (1997) and Medeiros and Lopes (1996), in which the parasite was isolated from various tissues, suggested the importance of this species for disease spread.

Thus, assessing the genetic variability of $T$. gondii is useful for conducting epidemiological and biological studies and for diagnosis, either by assessing the risks associated with severe cases in a given population or by estimating prognosis in individual cases. In addition, the identification of recombinant strains associated with atypical cases of toxoplasmosis in animals and humans, including those in areas where contact between humans and wild animals has increased, might be related to severe cases of the disease (Demar et al., 2008).

Although many studies of toxoplasmosis have been performed in Brazil, there is a lack of data regarding genotyping variations and disease patterns in Santa Catarina state. A more accurate description of the epidemiological risk conferred by different genotypes in this state is important for a better understanding of disease prevalence in the state, and to adopt appropriate preventive measures. The aim of this study was to genetically characterize $T$. gondii isolates from naturally infected chickens (Gallus domesticus) from Santa Catarina state.

\section{MATERIAL AND METHODS}

Blood samples $(\mathrm{n}=133)$ were collected from free-range chickens (Gallus domesticus) in six mesoregions of Santa Catarina state (27 from Serrana, 30 from the western region, 18 from the southern region, 16 from the northern region, 13 from Vale do Itajaí, and 29 from Grande Florianópolis).

The detection of $\operatorname{IgG}$ antibodies against $T$. gondii was performed by an immunofluorescence assay (IFA) as described by Camargo (1964), using tachyzoites of the RH strains as the antigen. Positive and negative control sera were used for 
comparison purposes. Titers of 16 were considered positive (Galli et al., 2008).

Thirty chickens that had titers $\geq 64$ for $T$. gondii were selected for bioassay (11 from Serrana, seven from the western region, four from the southern region, three from the northern region, three from Grande Florianópolis, and two from Vale do Itajaí). The birds were slaughtered in accordance with the principles of bioethics for removal of the heart and brain, which were digested in an acidic solution of pepsin. Isolates were inoculated intraperitoneally into mice (Dubey, 1998).

All inoculated mice were examined daily for clinical signs of toxoplasmosis (apathy, anorexia, depression, enophthalmos, and goose bumps) and animals with signs of disease were euthanized to collect peritoneal exudates and identify $T$. gondii tachyzoites. Animals that showed no clinical signs were euthanized in accordance with the principles of bioethics and animal welfare regulations at eight weeks postinoculation (PI) and blood and brain tissue were collected for IFA and detection of cysts (using a squash smear), respectively.

A total of 11 isolates $(\mathrm{Ck} 3, \mathrm{Ck} 32, \mathrm{Ck} 35, \mathrm{Ck} 56$, Ck63, Ck89, Ck102, Ck103, Ck125, Ck127, and Ck128) obtained from the mouse bioassay were subjected to DNA extraction, which was stored at $-20{ }^{\circ} \mathrm{C}$ until PCR-RFLP analysis. DNA was extracted from cyst tissue and/or tachyzoites using a commercial DNA extraction kit (Easy$\mathrm{DNA}^{\mathrm{TM}}$, Invitrogen, USA), according to the manufacturer's instructions.

The genotypic characterization of $T$. gondii isolates was performed at the Department of Preventive Veterinary Medicine, Londrina State University, using 12 genetic markers (SAG1, 5'3'SAG2, alt. SAG2, SAG3, BTUB, GRA6, c228, c29-2, L358, PK1, Apico, and CS3) as previously described (Pena et al., 2008; Su et al., 2010).

DNA target sequences were first amplified by multiplex-PCR using external primers for all markers, followed by nested-PCR for individual markers. Autoclaved pure water and PCR reagents without any DNA were used as negative controls for the reaction. DNA from eight reference strains (GT1, PTG, CTG, TgCgCa1,
MAS, TgCatBr5, TgCatBr64, and TgRsCr1) was used as a positive control. The results were compared to data from genotypes deposited in the ToxoDB (http://toxodb.org/toxo/) for the identification of obtained isolates.

This project was approved by the Animal Research Ethics Committee of CAV/UDESC (protocol $\mathrm{n}^{\mathrm{o}}$ 1.02/10) on June 14, 2010.

\section{RESULTS AND DISCUSSION}

Of 133 chicken sera analyzed by IFA, 84 (63.16\%) were positive for $T$. gondii $\mathrm{IgG}$ antibodies, including $22.62 \%$ (19/84) from the Serrana, 22.62\% (19/84) from the west, $19.05 \%$ (16/84) from the south, $15.47 \%$ (13/84) from the north, $2.38 \%(2 / 84)$ from the Vale do Itajaí, and $17.86 \%(15 / 84)$ from Grande Florianópolis mesoregions. The antibody titers observed were 1:16 (28), 1:64 (31), 1:256 (21), and 1:1024 (four).

No chickens showed clinical signs of toxoplasmosis and the majority $(70.2 \%, 59 / 84)$ had low IgG antibody titers $(\leq 1: 64)$, suggesting the occurrence of chronic infection in the population of birds analyzed.

Of the 108 inoculated mice, $23(28.05 \%)$ had antibodies against $T$. gondii, with titers ranging 16 to 256. From 30 chickens, 11 strains were obtained (eight from cerebral cysts, one from tachyzoites peritoneal exudate, and two from tachyzoites and cysts). Although three isolates caused death in mice between 11 and 19 days PI (samples 63, 103, and 127), we could not determine the virulence in mice because the infective doses from the mouse bioassays were unknown.

These results were unexpected when compared to other Brazilian isolates, as most strains cause high mortality rates in mice, with death occurring after only a few days PI (Pena et al., 2006; Su et al., 2006; Dubey et al., 2007a; Dubey et al., 2008; Ferreira et al., 2011).

Similar results to this study were reported by Soares et al. (2011), in Mato Grosso do Sul state; specifically, from 23 isolates, five were identified as virulent. Pena et al. (2008) also reported a low rate (or absence) of mortality in mice inoculated with $T$. gondii isolated from cats 
in São Paulo state, and these isolates were characterized as non-virulent strains.

In eight of the 11 obtained isolates, genotyping was successfully performed. Among the isolates, none were of clonal type I, II, or III. Three new genotypes were identified, referred to as NEO1, $\mathrm{NEO} 2$, and NEO3, and three genotypes were identified that been previously described (\#26, \#120 and \#53) (Tab. 1).

Table 1. Genotyping of Toxoplasma gondii isolates from naturally infected chickens (Gallus domesticus) in Santa Catarina state, by PCR-RFLP

\begin{tabular}{|c|c|c|c|c|c|c|c|c|c|c|c|c|c|c|c|c|}
\hline \multirow[b]{2}{*}{ Chicken } & \multirow[b]{2}{*}{ Mesoregion } & \multicolumn{12}{|c|}{ Genetic marker } & \multirow[b]{2}{*}{ Genotype * } & \multirow{2}{*}{ References** } & \multirow{2}{*}{ Species } \\
\hline & & SAG1 & $3^{\prime}-5-\mathrm{SAG} 2$ & alt. SAG2 & SAG3 & BTUB & GRA6 & C22-8 & $\mathrm{C} 29-2$ & L358 & PK1 & Apico & CS3 & & & \\
\hline 03 & Serrana & nd & nd & nd & nd & nd & nd & nd & nd & nd & nd & nd & nd & - & & \\
\hline 32 & Sul & $\mathrm{II} / \mathrm{III}$ & III & III & III & III & III & I & III & III & I & III & III & $\# 26$ & $1,2,3$ & Chicken \\
\hline 35 & Sul & II/III & III & III & III & III & III & I & III & III & I & III & III & \#26 & $1,2,3$ & $\begin{array}{c}\text { Cat, } \\
\text { Chicken }\end{array}$ \\
\hline 56 & Norte & $\mathrm{u}-1$ & I & II & III & III & III & III & III & III & III & III & III & NEO1 & - & - \\
\hline 63 & Serrana & $\mathrm{u}-1$ & I & nd & III & nd & III & $\mathrm{u}-1$ & nd & I & nd & I & nd & - & - & - \\
\hline 89 & Vale do Itajaí & I & III & III & III & III & III & I & I & III & III & III & II & $\# 120$ & 4,5 & Cat \\
\hline 102 & Oeste & I & III & III & III & III & III & I & I & III & III & III & II & $\# 120$ & 4,5 & Cat \\
\hline 103 & Oeste & $\mathrm{u}-1$ & I & II & III & III & III & II & I & I & III & I & III & $\# 53$ & 7,8 & $\begin{array}{c}\text { Chicken, } \\
\text { Dog }\end{array}$ \\
\hline 125 & $\begin{array}{c}\text { Grande } \\
\text { Florianópolis }\end{array}$ & II/III & nd & III & nd & nd & nd & nd & nd & III & nd & III & nd & - & - & - \\
\hline 127 & $\begin{array}{l}\text { Grande } \\
\text { Florianópolis }\end{array}$ & $\mathrm{u}-1$ & I & II & III & III & II & $\mathrm{u}-1$ & III & III & III & I & II & $\mathrm{NEO} 2$ & - & - \\
\hline 128 & $\begin{array}{c}\text { Grande } \\
\text { Florianópolis }\end{array}$ & $\mathrm{u}-1$ & I & II & III & III & III & III & III & III & III & III & III & NEO3 & - & - \\
\hline 128 & $\begin{array}{c}\text { Grande } \\
\text { Florianópolis }\end{array}$ & $\mathrm{u}-1$ & I & II & III & III & III & II & I & I & III & I & III & $\# 53$ & 7,8 & $\begin{array}{c}\text { Chicken, } \\
\text { Dog }\end{array}$ \\
\hline 128 & $\begin{array}{c}\text { Grande } \\
\text { Florianópolis }\end{array}$ & I & III & III & III & III & III & I & I & III & III & III & II & $\# 120$ & 4,5 & Cat \\
\hline
\end{tabular}

* Genotype according ToxoDB/nd = not determined

**1, Pena et al., 2006; 2, Pena et al., 2008; 3, Dubey et al., 2007b; 4, Dubey et al., 2004; 5, Su et al., 2006; 7, Dubey et al., 2008; 8, Dubey et al., 2007c.

Recently, the recombinant characteristic of Brazilian isolates was described by several authors (Dubey et al., 2011; Ferreira et al., 2011; Frazão-Teixeira et al., 2011; Soares et al., 2011; Muradian et al., 2012), and results in higher variability of these protozoa in the country. These genotypes, considered atypical and referred to as "new variant" by Sibley et al. (2009), can arise from somatic mutations, can be the result of sexual recombination between three clonal lineages (Type I, II, and III), or can also represent entirely new genotypes.

The isolates from samples 03, 63, and 125 were not characterized because it was not possible to amplify all markers (designated as "nd" in Tab. 1); however, PCR-RFLP 18S rDNA was performed to differentiate these isolates from other apicomplexans (Neospora spp., and Sarcocystis spp.), and these were confirmed as $T$. gondii. One possible explanation for the inability to characterize these isolates was a low concentration of genetic material.

In sample 128, from the Grande Florianópolis mesoregion, there were three different genotypes, specifically, NEO3, \#53, and \#120 from the same chicken, representing a mixed infection. A possible explanation for this could be the history of animal movement to different properties distant from each other, or this bird could be subjected to different sources of infection on the same property. Other authors also reported mixed infection for this species; for example, Dubey et al. (2006) identified four such isolates (TgCkNi2, 7, 46, and 47). Mixed infection was also reported by Dubey et al. (2009) in a cat.

In this study, genotype \#26 was identified in birds from the south mesoregion. Using the mouse bioassay, this isolate was obtained only 
from cysts and mortality was not verified. This genotype was previously identified in cats from São Paulo (Pena et al., 2006; Pena et al., 2008) and in chickens from Rio Grande do Sul state (Dubey et al. 2007a), which demonstrates the importance of these animals (chickens) as $T$. gondii reservoirs for definitive hosts. The fact that the same recombinant genotypes have been found in different geographic regions and different animal species shows that their distribution is not limited by distance or host species; however, in Santa Catarina state, its distribution appears to be limited to the south mesoregion.

The genotype \#120, obtained from chickens from Vale do Itajaí (Sample 89), the west (Sample 102), and Grande Florianópolis (Sample 128) mesoregions seems to be well distributed in the state. These isolates, obtained from cysts for all three samples, did not cause mortality in mice. Dubey et al. (2004) and $\mathrm{Su}$ et al. (2006) described the same genotype in cats, and unlike the results of the present study, this strain was considered virulent for mice.

Genotype \#53, obtained from birds from the west (Sample 103) and Grande Florianópolis (Sample 128) mesoregions, was previously described in chickens in Paraná (Dubey et al., 2008) and dogs in São Paulo (Dubey et al., 2007b). In the mouse bioassay, cysts and tachyzoites were observed for sample 103 (25\% mouse mortality), and for sample 128 , only cysts were identified, without mortality. These data reveal that the same genotype might exhibit different behaviors (generation of cysts and/or tachyzoites and mortality rate); this is possibly due to the amount of inoculum, since in the mouse bioassay the infective doses are not known.

The genotype NEO1 was identified in a chicken (56) from the north mesoregion, of which only cysts were obtained and this isolate did not cause death in mice.

The NEO2 genotype, observed from an isolate obtained from bird 127 (Grande Florianópolis mesoregion) produced tissue cysts and tachyzoites (based on the mouse bioassay) and had a mortality rate of $25 \%$ (1/4) of inoculated mice. For this sample, one mouse (127A) showed clinical signs (apathy, anorexia, dehydration, enophthalmos, creeping, and abdominal bulging) and died 11 days PI, but few tachyzoites were isolated from this animal. For the other three mice $(127 \mathrm{~B}, 127 \mathrm{C}$, and 127D) inoculated with this samples, cysts were observed. Mouse 127A2, which was reinoculated by peritoneal lavage, presented brain cysts and a high antibody titer (256). Due to the low concentration of tachyzoites recovered from mouse $127 \mathrm{~A}$, it was speculated that the reinoculated animal (127A2) developed immunity to $T$. gondii and expressed the chronic form of the disease.

The NEO3 genotype, detected in chicken 128, from the Grande Florianópolis mesoregion, induced formation of brain cysts in all mice without causing mortality.

Based on genotyping results, there was a predominance of type III alleles (Tab. 1), featuring those of strains isolated from asymptomatic animals, and representing isolates with less virulence (for mice), which normally result in the chronic form of the disease with the formation of tissue cysts, as observed in this study.

Early studies of $T$. gondii genotyping used only one genetic marker, SAG2. The results based on only one locus do not allow for the observation of recombinant isolates, thus reducing assay sensitivity/specificity. Current studies use 11 genetic markers (SAG1, SAG2, alt. SAG2, SAG3, BTUB, GRA6, c22-8, c29-2, L358, PK1, and Apico), which permits the identification of recombinant parasite genotypes and provides greater accuracy.

In Brazil, analysis by PCR-RFLP revealed several atypical $T$. gondii isolates, and identified recombination between alleles (Beltrame et al., 2012; Andrade et al., 2013; Pena et al., 2013). This parasite was originally considered clonal with low genetic diversity. However, through studies involving isolates from animals and humans from different geographic regions, it was revealed to have high genetic variability compared to that observed in previous reports. These studies thus demonstrated that $T$. gondii isolates from Brazil are genetically different from those of North America and Europe (Pena et al., 2008). 


\section{CONCLUSION}

Different profiles were identified in isolates from distinct regions and the results obtained from the PCR-RFLP analysis showed the presence of six different genotypes, all recombinant. Thus, the distribution of $T$. gondii genotypes in Santa Catarina state corroborates the results of other studies performed in Brazil, confirming the recombinant pattern found in this country.

\section{REFERENCES}

ANDRADE, M.M.C.; PINHEIRO, B.V.; CUNHA, M.M. et al. New genotypes of Toxoplasma gondii obtained from farm animals in Northeast Brazil. Res. Vet. Sci., v.3, p.587$589,2013$.

BELTRAME, M.A.V.; PENA, H.F.J.; TON, N.C. et al. Seroprevalence and isolation of Toxoplasma gondii from free-range chickens from Espírito Santo state, southeastern Brazil. Vet. Parasitol., v.188, p.225-230, 2012.

CAMARGO, M.E. Improvided technique of indirect immunofluorescence for serological diagnosis of toxoplasmosis. Rev. Inst. Med. Trop., v.6, p.117-118, 1964.

DARDÉ, M.L.; AJZENBERG, D.; SMITH, J. Population structure and epidemiology of Toxoplasma gondii. In: WEISS, L.M.; KIM, K. (Eds.). Toxoplasma gondii the model apicomplexan - perspectives and methods. London: [Elsevier], 2007. p.49-80.

DEMAR, M.; AJZENBERG, D.; SERRURIER, B. et al. Case report: atypical Toxoplasma gondii strain from a free-living Jaguar (Panthera onca) in French Guiana. Am. J. Trop. Med. Hyg., v.78, p.195-197, 2008.

DUBEY, J.P. Refinement of pepsin digestion method for isolation of Toxoplasma gondii from infected tissues. Vet. Parasitol., v.74, p.75-77, 1998.

DUBEY, J.P.; SUNDAR, N.; GENNARI, S.M. et al. Biologic and genetic comparison of Toxoplasma gondii isolates in free-range chickens from the northern Pará state and the southern state Rio Grande do Sul, Brazil revealed highly diverse and distinct parasite populations. Vet. Parasitol., v.143, p.182-188, 2007a.
DUBEY, J.P.; ZHU, X.Q.; SUNDAR, N. et al. Genetic and biologic characterization of Toxoplasma gondii isolates of cats from China. Vet. Parasitol., v. 145, p.352-356, 2007b.

DUBEY, J.P.; GENNARI, S.M.; SUNDAR, N. et al. Diverse and atypical genotypes identified in Toxoplasma gondii from dogs in Sao Paulo, Brazil. J. Parasitol., v. 93, p.60-64, 2007c.

DUBEY, J.P.; NAVARRO, I.T.; SREEKUMAR, C. et al. Toxoplasma gondii infections in cats from Paraná, Brazil: seroprevalence, tissue distribution, and biologic and genetic characterization of isolates. J. Parasitol., v.90, p.721-726, 2004.

DUBEY, J.P.; PASSOS, L.M.F.; RAJENDRAN, C. et al. Isolation of viable Toxoplasma gondii from guinea fowl (Numida meleagris) and domestic rabbits (Oryctolagus cuniculus) from Brazil. J. Parasitol., v.97, p.842-845, 2011.

DUBEY, J.P.; RUFF, M.D.; CAMARGO, M.E. et al. Serologic and parasitologic responses of domestic chickens after oral inoculation with Toxoplasma gondii oocysts. J. Parasitol., v.54, p.1668-1672, 1993.

DUBEY, J.P.; SUNDAR, N.; PINEDA, N. et al. Biologic and genetic characteristics of Toxoplasma gondii isolates in free-range chickens from Nicaragua, Central America. Vet. Parasitol., v.142, p.47-53, 2006.

DUBEY, J.P.; VELMURUGAN, G.V.; CHOCKALINGAM, A. et al. Genetic diversity of Toxoplasma gondii isolates from chickens from Brazil. Vet. Parasitol., v.157, p.299-305, 2008.

DUBEY, J.P.; VELMURYGAN, G.V.; ALVARADO-ESQUIVEL, C. et al. Isolation of Toxoplasma gondii from animals in Durango, Mexico. J. Parasitol., v.95, p.319-322, 2009.

FERREIRA, I.M.R.; VIDAL, J.E.; MATTOS, C.C.B. et al. Toxoplasma gondii isolates: multilocus RFLP-PCR genotyping from human patients in São Paulo State, Brazil identified distinct genotypes. Exp. Parasitol., v.129, p.190195, 2011.

FRAZÃO-TEIXEIRA, E.; SUNDAR, N.; DUBEY, J.P. et al. Multi-locus DNA sequencing of Toxoplasma gondii isolated from Brazilian pigs identifies genetically divergent strains. Vet. Parasitol., v.175, p.33-39, 2011. 
GALLI, S.; BELINATO, F.C.; LUCAS, T.M. et al. Infecção de frangos domésticos (Gallus gallus) com cepas geneticamente distintas de Toxoplasma gondii. Vet. Zootec., v.15, p.542550, 2008.

KANETO, C.N.; COSTA. A.J.; PAULILLO, C. et al. Experimental toxoplasmosis in broiler chicks. Vet. Parasitol., v.69, p.203-210, 1997.

LITERÁK, I.; HEJLÍCEK, K. Incidence of Toxoplasma gondii in population of domestic birds in the Czech Republic. Avian Pathol., v.22, p.275-281, 1993.

MAUBON, D.; AJZENBERG, D.; BRENIERPINCHART, M.P. et al. What are the respective host and parasite contributions to toxoplasmosis? Trends Parasitol., v.24, p.299-303, 2008.

MEDEIROS, S.M.; LOPES, C.W.G. Pleomorfismo de uma amostra acistogênica de Toxoplasma gondii Nicolle \& Manceaux, 1909 (Apicomplexa: Toxoplasmatinae) isolada de uma galinha naturalmente infectada. Rev. Bras. Med. Vet., v.18, p.71-73, 1996.

MURADIAN, V.; FERREIRA, L.R.; LOPES, E.G. et al. A survey of Neospora caninum and Toxoplasma gondii infection in urban rodents from Brazil. J. Parasitol., v.98, p.128-134, 2012.

PENA, H.F.; SOARES, R.M.; AMAKU, M. et al. Toxoplasma gondii infection in cats from Sao Paulo state, Brazil: seroprevalence, oocyst shedding, isolation in mice, and biologic and molecular characterization. Res. Vet. Sci., v.81, p.58-67, 2006.
PENA, H.F.J.; GENNARI, S.M.; DUBEY, J.P.; SU, C. Population structure and mouse virulence of Toxoplasma gondii in Brazil. Int. J. Parasitol., v.38, p.561-569, 2008.

PENA, H.F.J; VITALIANO, S.N.; BELTRAME, M.A.V. et al. PCR-RFLP genotyping of Toxoplasma gondii from chickens from Espírito Santo state, Southeast region, Brazil: new genotypes and a new SAG3 marker allele. Vet. Parasitol., v.192, p.111-117, 2013.

SIBLEY, L.D.; KHAN, A.; AJIOKA, J.W.; ROSENTHAL, B.M. Genetic diversity of Toxoplasma gondii in animals and humans. Philos. T. Roy. Soc. B., v.364, p.2749-2761, 2009.

SIBLEY, L.D.; KHAN, A.; AJIOKA, J.W.; ROSENTHAL, B.M. Genetic diversity of Toxoplasma gondii in animals and humans. Philos. Trans. Roy. Soc. B Biol. Sci., v.364, p.2749-2761, 2009.

SOARES, M.S.; SILVEIRA, L.H.; SILVA, A.V. et al. Genotyping of Toxoplasma gondii isolates from free range chickens in the Pantanal area of Brazil. Vet. Parasitol., v.178, p.29-34, 2011.

SU, C.; SHWAB, E.K.; ZHOU, P. et al. Moving towards an integrated approach to molecular detection and identification of Toxoplasma gondii. Parasitology, v.137, p.1-11, 2010.

SU, C.; ZHANG, X.; DUBEY, J.P. Genotyping of Toxoplasma gondii by multilocus PCR-RFLP markers: a high resolution and simple method for identification of parasites. Int. J. Parasitol., v.36, p.841-848, 2006. 